\title{
Cancer cure - The protocol and explanation
}

\author{
Andrew Hague* \\ Professor of Advanced Medicine, President, Cellsonic, Manufacturers of Medical Equipment, UK
}

\begin{abstract}
Discovering the cure for cancer. Understanding the cause of cancer. Diagnosing by measuring electrical properties. A plan to check the whole population to prevent deaths from cancer.
\end{abstract}

\section{Case report}

Our distributor in Bangladesh had been hardworking and loyal for many years. When he asked for help with his prostate cancer, I knew I had to do something. It was his last chance.

The first question for me was, would using CellSonic be safe? We know that this technology, in various forms, had been applied in much more powerful blasts on to kidney stones for forty years in all countries with millions of patients and never a report of causing cancer.

My involvement with urology began with the first lithotripter in Britain at St Thomas' Hospital in London in 1987. By now I have probably been in this industry longer than anyone else in the world, so I know it inside out, all the scandals and where the truth lies and one fact stood out - cancer was never caused. We all know that bad news travels fast and of all the rumours and stories going around, cancer was never mentioned. We could not get better than forty years of safety trials.

The second question was, would CellSonic do any good? There was a hypothesis that pressure kills cancer [1]. It was worth a try. Kidney stones are broken by pressure non-invasively.

I developed a protocol, briefed our team in Mumbai and invited the patient. He eventually got visas for his wife and himself and he arrived looking more dead than alive. The next morning, he had the first treatment. Three hundred pulses at energy level 4 . The machine fires at four a second so the whole session took only a few minutes. There was no pain and the only problem was embarrassment because the treatment has to be around the genitals. My suggestion was that the treatment be repeated every two days in case some parts were missed on the previous session. I telephoned on the third day. The doctor immediately replied because he had just finished the second treatment. He said the patient was feeling better. I did not believe him. Recovery so soon was not expected. Joking about a killer disease was not ethical and I said so. He handed the phone to the patient.

"Hello Andrew, I am better now."

I was furious.

"Don’t joke! You were dying last week. Are you going mad?"

"No. I'm fine. Feel a lot better. There has been a change."

I could not believe it. He and he his wife spent the afternoon walking around the zoo enjoying themselves. Two days later he had another treatment, which we now know was unnecessary, and the following week blood tests confirmed that his cancer had gone.

We have full medical documentation before and after the treatments.

The Mumbai team carried out cancer treatments on more patients with the same results; on the third day the patient proclaimed they were alright. What was happening was evident. How is was happening was still to be explained.

The most sceptical of all was me. This was my money and reputation at stake.

\section{Electrical properties}

Nevertheless, I had to talk about it. Treatments using the same protocol were done in Peru, Germany, Switzerland and Mexico and they all had the same results. It gave us a broad range of cancers including brain tumours. We were learning and when I lectured at a university in England to the professors of the electro-medical faculty, they too became excited. I had found the cure; they had the diagnosis. They were measuring the permittivity of tissue which highlighted the difference between healthy cells and cancer. This was a sort of resistance and it could be detected electrically.

What we were doing was switching the electrical polarity of the cells back to the correct alignment. Instead of replicating mutant cells, CellSonic VIPP caused the cells to simply replicate themselves correctly. The insight was that electrical properties of cancer cells are the clue to the cure [2].

Go back to the beginning. Before life on earth. Outside the earth, up in the heavens is the ionosphere. In it is the Appleton layer, identified by Edward Appleton, one of Britain's greatest scientists [3]. From this layer is emitted an electro-magnetic field of 7.83 Herz as calculated in 1952 by Otto Schuman [4]. Even before any life on earth, there was an electromagnetic field into which all life grew. Therefore, electrical properties

${ }^{*}$ Correspondence to: Andrew Hague, Professor of Advanced Medicine, President, Cellsonic, Manufacturers of Medical Equipment, UK, Tel: +1 315210 6307; E-mail: cellsonic.beauty@gmail.com

Received: March 04, 2019; Accepted: March 20, 2019; Published: March 22, 2019 
of cells are fundamental and surprisingly ignored by medicine of the last century.

\section{Results}

Immediately I saw that we had moved from a medical problem to a commercial and educational problem. Explaining to oncologists that cancer could not be cured by drugs because it is not a bio-chemical problem would either take years or be impossible. The only way forward is to prove by demonstration. At least we have the evidence of patients.

CellSonic is now upscaling the diagnostic prototype so that all people can be checked at six monthly intervals. If any cancer is found before that person is aware, it can be stopped by a quick zap from the CellSonic VIPP machine. The target is to diagnose and cure in twenty minutes.

Cancer cannot be prevented. It is the inevitable result of trillions of cells replicating continuously and some mistakenly mutating. Those mutations, we call cancer. The immune system is there to knock out the incipient cancers and for those of us who stay healthy, that is how we survive. Present the immune system with something too difficult, like a lung full of tobacco tar, and cancers continue to grow.
We know all the causes of cancer and to the list must be added electrical fields. Many more power cables are around us than before and this affects our bodies. Further research has to be done to know what is safe or not. An interesting study has confirmed that a smartphone conversation lasting beyond six minutes with the phone to the ear will be damaging the brain.

Over three million street corner, drop-in clinics are needed worldwide to carry out the diagnose and cure programme. This is a huge undertaking for which CellSonic now has the plans and finance. No one should die of cancer. Of course, we shall die of other causes whilst cancer will be the disease that can be stopped before it becomes fatal. Importantly, only the local clinic will hold data on the patient. There will be no central data bank available to hackers.

\section{References}

1. Li Ting Yi, Jing Liu (2013) Mechanical therapy as a potential green way to attack cancer disease. Medical Physics.

2. Steve Haltiwanger (2018) The electrical properties of cancer cells. Cancer

3. https://en.wikipedia.org/wiki/Edward_Victor_Appleton

4. https://en.wikipedia.org/wiki/Winfried_Otto_Schumann

Copyright: $\odot 2019$ Hague A. This is an open-access article distributed under the terms of the Creative Commons Attribution License, which permits unrestricted use, distribution, and reproduction in any medium, provided the original author and source are credited. 